\title{
Survey of Zoonotic Trematode Metacercariae in Fish from Irrigation Canal of Togyo-jeosuji (Reservoir) in Cheorwon- gun, Gangwon-do, Republic of Korea
}

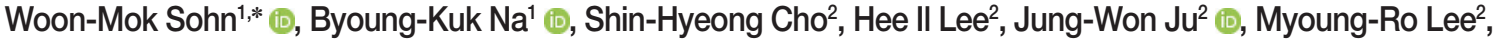 \\ Eun-Joo Lim³ ${ }^{3}$, Sung Yong Son ${ }^{3}$, Eunmi Ko ${ }^{3}$, Jaeseok Choi ${ }^{4}$ \\ ${ }^{1}$ Department of Parasitology and Tropical Medicine, and Institute of Health Sciences, Gyeongsang National University College of Medicine, Jinju \\ 52727, Korea; '2Division of Vectors and Parasitic Diseases, Korea Disease Control and Prevention Agency, Osong 28159, Korea; ${ }^{3}$ Infectious Disease \\ Intelligence Division, Gangwon Institute of Health and Environment, Chuncheon 24203, Korea; ${ }^{4}$ Research Center for Fish Environmental Institute/ \\ Wildife and Fish Research \& Conservation Center, Kangwon National University, Chuncheon 24341, Korea
}

\begin{abstract}
The infection status of zoonotic trematode metacercariae (ZTM) was investigated in total 568 freshwater fishes (19 species) from the irrigation canal of Togyo-jeosuji (Reservoir) in Cheorwon-gun, Gangwon-do, the Republic of Korea for 3 years (2018-2020). All fishes were examined using the artificial digestion method. The metacercariae of Clonorchis sinensis (CsMc) were detected in 180 (43.8\%) out of 411 fish of positive species, and their infection intensity was 38 per fish infected (PFI). Especially, in 2 fish species, i.e., Pseudorasbora parva and Puntungia herzi, the prevalence was $82.1 \%$ and $31.3 \%$, and the infection intensity with CsMc was 88 and $290 \mathrm{PFI}$, respectively. Metagonimus spp. metacercariae (MsMc) were found in 403 (74.1\%) out of 544 fish of positive species, and their infection intensity was 62 PFI. In the pale chub, Zacco platypus, the prevalence of MsMc was $98.6 \%$, and their infection intensity was $144 \mathrm{PFI}$. Centrocestus armatus metacercariae were detected in 171 (38.9\%) out of 440 fish of positive species, and their infection intensity was 1,844 PFI. Echinostoma spp. metacercariae were found in 94 (19.6\%) out of 479 fish of positive species, and their infection intensity was $3 \mathrm{PFI}$. Metorchis orientalis metacercariae were detected in 43 (29.3\%) out of 147 fish of positive species, and their infection intensity was $4 \mathrm{PFI}$. By the present study, it has been confirmed that some species of ZTM, including CsMc and MsMc, are prevalent in fishes from the irrigation canal of Togyo-jeosuji in Cheorwon-gun, Gangwon-do, Korea.
\end{abstract}

Key words: Clonorchis sinensis, Metagonimus spp. Centrocestus armatus, Echinostoma spp., Metorchis orientalis, zoonotic trematode metacercaria, Togyo-jeosuji, Cheorwon-gun, Gangwon-do

Nowadays, infection of fishborne zoonotic trematodes (FZT), including Clonorchis sinensis, is one of the important public health problems in the Republic of Korea (=Korea) [1]. The Division of Vectors and Parasitic Diseases of Korea DCPA (Korea Disease Control and Prevention Agency) has continuously paid attention to the decrease of the endemicity of FZT infections in endemic riverside areas of major rivers in southern regions of Korea [2-5]. The team also concentrated on the infection status of zoonotic trematode metacercariae (ZTM) in freshwater fishes, the infection sources of FZT, to surveil the epidemiological situations in water systems of major rivers in Korea [6-16]. In the water systems of Gangwon-do (do=province),

- Received 20 May 2021, revised 16 July 2021, accepted 21 July 2021.

*Corresponding author (wmsohn@gnu.ac.kr)

(c) 2021, Korean Society for Parasitology and Tropical Medicine

This is an Open Access article distributed under the terms of the Creative Commons Attribution Non-Commercial License (https://creativecommons.org/licenses/by-nc/4.0) which permits unrestricted non-commercial use, distribution, and reproduction in any

medium, provided the original work is properly cited.
Cho et al. [6] investigated the infection status of $C$. sinensis metacercariae (CsMc) in fishes from Gangwon-do, where they surveyed fishes from 3 wide regions by the latitudinal levels of the Korean peninsula. Cho et al. [7] also surveyed the infection status of ZTM in fishes from Gangwon-do, Korea. The infections of digenetic trematode metacercariae (DTM), including C. sinensis, were investigated in freshwater fish from Hantan-gang (gang means river) and Imjin-gang in northern regions of Korea [8]. Recently, Sohn et al. [15] reported the infection status with DTM in fishes from coastal lakes in Gangwon-do, Korea.

Togyo-jeosuji (Reservoir) is a lake for agricultural water supply located in Dongsong-eup (eup=township), Cheorwongun (gun=county), Gangwon-do, Korea. This lake is famous for the visiting site of migratory birds, especially avian species at extinct crisis, crane and white-naped crane, Grus spp. [17]. An epidemiological survey on the infections of intestinal parasites among inhabitants and ZTM in fishes was performed in 
riverside areas of Hantan-gang in Cheorwon-gun, Gangwondo [18]. A lot of fishes from Hantan-gang, adjacent river of Togyo-jeosuji, was also investigated to reveal the infection status of ZTM in previous studies [7,8]. However, the infection status of ZTM has not been examined in fishes from Togyo-jeosuji. Therefore, we intentionally investigated the infection status of ZTM in fishes from the irrigation canal of Togyo-jeosuji in Cheorwon-gun, Gangwon-do, Korea.

We collected lots of freshwater fishes in the irrigation canal of Togyo-jeosuji (Latitude: 35.980225; Longitude: 127.393880), in Dongsong-eup, Cheorwon-gun, Gangwon-do for 3 years (2018-2020). All collected fishes were transferred to the laboratory of the Department of Parasitology and Tropical Medicine, Gyeongsang National University College of Medicine, Jinju, Korea. The length and weight of fish were individually measured, and the fish species was identified [19]. Individual fish was finely ground in a mortar with pestle, the ground fish meat was mixed with artificial gastric juice, and the mixture was incubated at $36^{\circ} \mathrm{C}$ for about $2 \mathrm{hr}$. The digested material was filtered with $1 \times 1 \mathrm{~mm}$ of mesh, and washed with $0.85 \%$ saline until the supernatant became clear. The sediment was carefully examined under a stereomicroscope. The metacercariae of each species (only ZTM) were separately collected viewing from the general morphological features and were counted to get hold of the prevalence (\%) and intensity of infection (No. of ZTM per fish infected) by fish species [20].

A total of 200 freshwater fish in 15 species were examined in 2018. The fish species (no. of fish) examined were Zacco platypus (54), Carassius auratus (25), Acheilognathus rhombeus
(25), Pseudorasbora parva (24), Hemibarbus labeo (15), Abbotina rivularis (14), Zacco koreanus (12), Rhodeus ocellatus (10), Microphysogobio longidorsalis (8), Pungtungia herzi (4), Coreoleuciscus splendidus (2), Iksookimia koreensis (2), Micropterus salmoides (2), Pseudogobio esocinus (2), and Odontobutis interrupta (1). In 2019, a total of 188 freshwater fish in 12 species were examined. The fish species examined included Z. platypus (40), $H$. labeo (34), C. auratus (30), P. esocinus (28), M. salmoides (15), Lepomis macrochirus (11), Hemibarbus longirostris (8), P. parva (6), O. interrupta (6), Acanthorhodeus gracilis (5), P. herzi (3), and R. ocellatus (2). A total of 180 freshwater fish in 15 species were examined in 2020. The fish species examined were $Z$. platypus (45), P. parva (26), H. labeo (19), C. auratus (16), R. ocellatus (15), Acheilognathus lanceolatus (10), M. salmoides (10), P. herzi (9), P. esocinus (8), Z. koreanus (7), O. interrupta (5), A. rinularis (4), L. macrochirus (3), M. longidorsalis (2), and H. longirostris (1).

The metacercariae of $C$. sinensis were detected in $180(43.8 \%)$ out of 411 fish of the positive species, and their intensity of infection was 38 PFI. Especially in 3 fish species, i.e., P. parva, $P$. herzi, and A. gracilis, the prevalence was $82.1 \%, 31.3 \%$, and $100 \%$, and the infection intensity was 88, 290, and $125 \mathrm{PFI}$, respectively. The overall infection status by the fish species was presented in Table 1 . The prevalence of CsMc was gradually decreased by the year surveyed, $65.5 \%$ in $2018,44.4 \%$ in 2019 , and $26.7 \%$ in 2020. The intensity of infection with CsMc was highest in 2019 (49 PFI), followed by in 2020 (40 PFI) and 2018 (30 PFI) (Supplementary Table S1). Metagonimus spp. metacercariae were found in 403 (74.1\%) out of 544 fishes of the positive species, and their intensity of infection was 62 PFI.

Table 1. Infection status of Clonorchis sinensis metacercariae (CsMc) in fishes from the irrigation canal of Togyo-jeosuji in Cheorwongun, Gangwon-do, Korea

\begin{tabular}{lcccc}
\hline \multirow{2}{*}{ Fish species } & No. of fish examined & No. (\%) of fish infected & \multicolumn{2}{c}{ No. of CsMc detected } \\
\cline { 3 - 4 } & & & Range & Average \\
\hline Zacco platypus & 139 & $32(23.0)$ & $1-22$ & 3.7 \\
Hemibarbus labeo & 68 & $21(30.9)$ & $1-10$ & 2.4 \\
Pseudorasbora parva & 56 & $46(82.1)$ & $1-511$ & 87.9 \\
Pseudogobio esocinus & 38 & $10(26.3)$ & $1-10$ & 2.6 \\
Rhodeus ocellatus & 27 & $15(55.6)$ & $1-11$ & 3.1 \\
Acheilognathus rhombeus & 25 & $25(100)$ & $1-45$ & 9.9 \\
Abbotina rivularis & 18 & $13(72.2)$ & $2-60$ & 10.3 \\
Pungtungia herzi & 16 & $5(31.3)$ & $8-41$ & 290.0 \\
Microphysogobio longidorsalis & 10 & $2(20.0)$ & $1-8$ & 24.5 \\
Hemibarbus longirostris & 9 & $6(66.7)$ & $16-233$ & 3.0 \\
Acanthorhodeus gracilis & 5 & $5(100)$ & $1-654$ & 124.6 \\
Total & 411 & $180(43.8)$ & 37.8 \\
\hline
\end{tabular}


The infection status of MsMc by the fish species was designated in Table 2. Especially in case of the pale chub, Z. platypus, the prevalence was $98.6 \%$, and infection intensity was 144 PFI.

The metacercariae of Centrocestus armatus (CaMc) were found in 171 (38.9\%) out of 440 fishes of the positive species, and their intensity of infection was 1,844 PFI. Especially in 2 species of chubs, i.e., $Z$. platypus and $Z$. koreanus, the prevalence was $99.3 \%$ and $100 \%$, and the infection intensity was 2,130 and 1,118 PFI, respectively. Echinostoma spp., Metacercariae (EsMc) were detected in 94 (19.6\%) out of 479 fishes of the positive species, and their intensity of infection was $3 \mathrm{PFI}$. The metacercariae of Metorchis orientalis (MoMc) were detected in 43 (29.3\%) out of 147 fishes of the positive species, and their intensity of infection was 4 PFI. The infection status of CaMc, EsMc, and MoMc by the fish species was as shown in Table 2.

In this study, more than 5 species of ZTM, i.e., C. sinensis, Metagonimus spp. C. armatus, Echinostoma spp., and M. orientalis, were detected in fishes from the irrigation canal of Togyojeosuji in Cheorwon-gun, Gangwon-do, Korea. Their individual prevalence was $43.8 \%, 74.1 \%, 38.9 \%, 19.6 \%$, and $29.3 \%$, and the infection intensity was 38, 62, 1,844, 3, and 4 PFI, respectively. The prevalence of MsMc was generally higher than the other 4 species of ZTM. Meanwhile, the intensity of infection was relatively high-level in CaMc. However, the susceptibility indices (SI: prevalence $/ 100 \times$ mean no. of ZTM PFI) in each ZTM were relatively low $(16.6,45.9,717.3,0.6$, and 1.2).

A total of 568 fish in 19 species were examined in this study. Among them, Z. platypus (24.5\%) was most dominantly examined, and followed by C. auratus (12.5\%), H. labeo (12.0\%), P. parva (9.9\%), P. esocinus (6.7\%), R. ocellatus (4.8\%), M. salmoides (4.8\%), A. rhombeus (4.4\%), Z. koreanus (3.4\%), A. rivularis (3.2\%), and $P$. herzi (2.8\%). The remaining 8 fish species, i.e., L. macrochirus, O. interrupta, M. longidorsalis, A. lanceolatus, $H$. longirostris, A. gracilis, C. splendidus, and I. koreensis, were examined less than 14 fish individuals ( 8 fish in average). Moreover, 2 fish species, M. salmoides (large mouthed bass; $\mathrm{n}=27$ ) and $L$. macrochirus (blue gill; $\mathrm{n}=14$ ), were included as the exotic fish species. From the aforementioned situation of fish examined, such as the small number of fish species, the biased number of fish by the fish species and the prevalence of exotic fish species, we could know that the fish ecology is not so good in this survey region.

The metacercariae of C. sinensis were detected in 180 (43.8\%) out of 411 fishes in 11 (57.9\%) positive species, and their in- fection intensity was $38 \mathrm{PFI}$ in this study. However, in previous studies on metacercariae in fish from Gangwon-do, CsMc were detected in only fish from Hantan-gang in Cheorwon-gun [68]. Cho et al. [6] detected CsMc in 2 fish species, P. herzi $(60.0 \%)$ and S. japonicus coreanus (100\%), and the intensity of infection was 2.8 and 2.0 PFI, respectively. Later, Cho et al. [7] also found CsMc in 4 fish species, i.e., P. herzi, S. japonicus coreanus, A. rhombeus, and Ladislabia taczanowskii, from Hantangang; the prevalence was $29.8 \%$ (28/94) in 4 positive fish species, and the intensity of infection was 2.0 PFI. Sohn et al. [8] detected total 13 CsMc in 7 (7.4\%) out of 95 fishes in 3 species, i.e., P. herzi, Microphysogobio longidorsalis, and Hemibarbus mylodon, from Hantan-gang. When we compared the endemicity of CsMc in this study with the findings of previous studies performed in Hantan-gang, we could know that the endemicity of CsMc in fish from Togyo-jeosuji is much higher than that in fish from Hantan-gang. On the other hand, Sohn et al. [8] reported the similar prevalence $(40.0 \%)$ and infection intensity of CsMc (36 PFI) in fishes from Munsan-cheon (a stream of Imjin-gang), in Paju-si, Gyeonggi-do.

In this study, MsMc were detected in 403 (74.1\%) out of 544 fish in 15 (78.9\%) positive species, and their infection intensity was about 62 PFI. Cho et al. [7] detected MsMc from $74.3 \%$ (324/436) of fish from Hantan-gang for 3 years (2010, 2012, and 2013), and the overall intensity of infection was 32 PFI. Sohn et al. [8] also detected MsMc in 61.1\% (312/511) of fishes (in 19 spp.) from the water systems of Hantan-gang, and their intensity of infection was 48 PFI. Sohn et al. [8] also reported 59.0\% (113/191) MsMc prevalence and about 10 in intensity of infection in fishes from the water systems of Imjingang. Recently, Sohn et al. [21] reported 55.4\% and 57.7\% prevalence, and 96 and $138 \mathrm{MsMc}$ intensity in fishes from Seomjin-gang and Tamjin-gang, respectively. The prevalence of MsMc in this study is relatively higher than those of previous studies. However, infection intensities with MsMc are much higher in fish from Seomjin-gang and Tamjin-gang. One of the reasons is the presence of susceptible fish, Plecoglossus altivelis, in fishes from Seomjin-gang and Tamjin-gang.

On the other hand, the rasborinid fish, Z. platypus, Z. temminckii, Z. koreanus, and Opsarichthys uncirostris amurensis, are regarded as the index fish of MsMc survey in inland localities where the sweetfish, $P$. altivelis, are unavailable. In this study, the prevalence of MsMc in Z. platypus and Z. koreanus was $98.6 \%$ and $94.7 \%$, and the intensity of infection was 144 and $57 \mathrm{PFI}$, respectively. The prevalence of MsMc in rasborinid fish 
Table 2. Infection status of freshwater fish with zoonotic trematode metacercariae (ZTM) by fish species from the irrigation canal of Togyo-jeosuji, in Cheorwon-gun, Gangwon-do, Korea

\begin{tabular}{|c|c|c|c|c|c|c|c|c|c|}
\hline \multirow[b]{2}{*}{$\begin{array}{l}\text { Fish species } \\
\text { examined }^{\text {a }}\end{array}$} & \multirow[b]{2}{*}{$\begin{array}{l}\text { No. of fish } \\
\text { examined }\end{array}$} & \multicolumn{2}{|c|}{ Metagonimus spp. } & \multicolumn{2}{|c|}{ Centrocestus armatus } & \multicolumn{2}{|c|}{ Echinotoma spp. } & \multicolumn{2}{|c|}{ Metorchis orientalis } \\
\hline & & $\begin{array}{c}\text { Fish } \\
\text { infected } \\
(\%)\end{array}$ & $\begin{array}{c}\mathrm{Av} \\
\text { (range }^{\mathrm{b}}\end{array}$ & $\begin{array}{c}\text { Fish } \\
\text { infected } \\
(\%)\end{array}$ & $\begin{array}{c}\mathrm{Av} \\
(\text { range })^{\mathrm{b}}\end{array}$ & $\begin{array}{c}\text { Fish } \\
\text { infected } \\
(\%)\end{array}$ & $\begin{array}{c}\mathrm{Av} \\
(\text { range })^{\mathrm{b}}\end{array}$ & $\begin{array}{c}\text { Fish } \\
\text { infected } \\
(\%)\end{array}$ & $\begin{array}{c}\mathrm{Av} \\
(\text { range })^{\mathrm{b}}\end{array}$ \\
\hline $\begin{array}{l}\text { Zacco } \\
\text { platypus }\end{array}$ & 139 & 98.6 & $144(1-1,020)$ & 99.3 & $2,130(2-11,750)$ & 1.4 & $3(1-5)$ & 0 & - \\
\hline $\begin{array}{l}\text { Carassius } \\
\text { auratus }\end{array}$ & 71 & 63.4 & $19(1-100)$ & 1.4 & $1(-)$ & 7.0 & $3(1-5)$ & 0 & - \\
\hline $\begin{array}{l}\text { Hemibarbus } \\
\text { labeo }\end{array}$ & 68 & 79.4 & $10(1-57)$ & 5.9 & $2(1-3)$ & 30.9 & $4(1-15)$ & 0 & - \\
\hline $\begin{array}{l}\text { Pseudorasbora } \\
\text { parva }\end{array}$ & 56 & 87.5 & $10(1-78)$ & 3.6 & $1(-)$ & 26.8 & $2(1-4)$ & 50.0 & $3(1-12)$ \\
\hline $\begin{array}{l}\text { Pseudogobio } \\
\text { esocinus }\end{array}$ & 38 & 81.6 & $59(1-240)$ & 0 & - & 39.5 & $3(1-18)$ & 2.6 & $1(-)$ \\
\hline $\begin{array}{l}\text { Rhodeus } \\
\text { ocellatus }\end{array}$ & 27 & 74.1 & $7(1-30)$ & 3.7 & $2(-)$ & 0 & - & 0 & - \\
\hline $\begin{array}{c}\text { Micropterus } \\
\text { salmoides }\end{array}$ & 27 & 18.5 & $4(1-14)$ & 3.7 & $1(-)$ & 48.2 & $2(1-3)$ & 0 & - \\
\hline $\begin{array}{l}\text { Acheilognathus } \\
\text { rhombeus }\end{array}$ & 25 & 100 & $13(3-31)$ & 0 & - & 0 & - & 0 & - \\
\hline $\begin{array}{l}\text { Zacco } \\
\text { koreanus }\end{array}$ & 19 & 94.7 & $57(1-211)$ & 100 & $1,118(342-2,190)$ & 0 & - & 0 & - \\
\hline $\begin{array}{l}\text { Abbotina } \\
\text { rivularis }\end{array}$ & 18 & 33.3 & $3(1-9)$ & 16.7 & $20(3-39)$ & 5.6 & $1(-)$ & 50.0 & $3(1-8)$ \\
\hline $\begin{array}{l}\text { Pungtungia } \\
\text { herzi }\end{array}$ & 16 & 12.5 & $3(1-4)$ & 0 & - & 37.5 & $3(1-7)$ & 18.8 & $9(4-19)$ \\
\hline $\begin{array}{l}\text { Lepomis } \\
\text { macrochirus }\end{array}$ & 14 & 7.1 & $2(-)$ & 0 & - & 14.3 & $2(1-2)$ & 0 & - \\
\hline $\begin{array}{l}\text { Odontobutis } \\
\text { interrupta }\end{array}$ & 12 & 66.7 & $4(1-5)$ & 0 & - & 42.9 & $3(1-6)$ & 0 & - \\
\hline $\begin{array}{l}\text { Microphysogobio } \\
\text { longidorsalis }\end{array}$ & 10 & 0 & - & 0 & - & 10.0 & $2(-)$ & 10.0 & $36(-)$ \\
\hline $\begin{array}{l}\text { Acheilognathus } \\
\text { lanceolatus }\end{array}$ & 10 & 0 & - & 10.0 & $19(-)$ & 0 & - & 0 & - \\
\hline $\begin{array}{l}\text { Hemibarbus } \\
\text { longirostris }\end{array}$ & 9 & 88.9 & $7(2-18)$ & 0 & - & 66.7 & $4(1-10)$ & 11.1 & $1(-)$ \\
\hline $\begin{array}{l}\text { Acanthorhodeus } \\
\text { gracilis }\end{array}$ & 5 & 100 & $8(1-24)$ & 20.0 & $1(-)$ & 60.0 & $4(1-10)$ & 0 & - \\
\hline $\begin{array}{l}\text { Coreoleuciscus } \\
\text { splendidus }\end{array}$ & 2 & 0 & - & 0 & - & 0 & - & 0 & - \\
\hline $\begin{array}{l}\text { Iksookimia } \\
\text { koreensis }\end{array}$ & 2 & 0 & - & 0 & - & 0 & - & 0 & - \\
\hline Total & 568 & $74.1^{\mathrm{c}}$ & $62(1-1,020)$ & $38.9^{c}$ & $1,844(1-11,750)$ & $19.5^{c}$ & $3(1-18)$ & $29.3^{c}$ & $4(1-36)$ \\
\hline
\end{tabular}

${ }^{a} \mathrm{~A}$ total of 568 freshwater fishes in 19 species were examined. ${ }^{b}$ No. of metacercariae detected (Av: average). 'No. of ZTM positive fish/No. of fish examined in ZTM positive species $\times 100$.

from water systems of Hantan-gang and Imjin-gang was 73.9\% and $72.1 \%$, and their infection intensity was 43 and 19 PFI, respectively [8]. The MsMc prevalence in rasborinid fish from water systems of Seomjin-gang and Tamjin-gang was $89.2 \%$ and $89.0 \%$, and their infection intensity was 74 and $42 \mathrm{PFI}$, respectively [21]. From the findings of previous studies, we can suppose that the endemicity of MsMc in this study is much higher than those in previous studies performed in Seomjingang, Tamjin-gang, Hantan-gang, and Imjin-gang [7,8,21].

In this study, CaMc were detected in 171 (38.9\%) out of 440 fish of 10 positive species, from the irrigation canal of Togyojeosuji in Cheorwon-gun, Gangwon-do, Korea. The mean in- 
tensity of infection was 1,844 PFI. However, the prevalence was $99.3 \%$ and $100 \%$ in 2 species of chubs, $Z$. platypus and $Z$. koreanus, susceptible fish hosts of CaMc, and the mean intensity of infection was 2,130 and 1,118 PFI, respectively. The endemicity of CaMc in chubs from the irrigation canal of Togyojeosuji is higher than that from water systems of Seomjin-gang and Mangyeong-gang, but it is similar and/or lower than that from water systems of other major rivers in Korea [22].

The endemicity of EsMc was low in fish from the irrigation canal of Togyo-jeosuji in this study. They were detected in 94 (19.6\%) out of 479 fish of 13 positive species, and their mean intensity of infection was $3 \mathrm{PFI}$. Moreover, in the dark sleeper, O. interrupta, the susceptible fish host for Isthmiophora hortensis [23], the EsMc prevalence was $42.9 \%$, and the mean intensity of infection was 2.5 PFI in this study. Recently, Sohn et al. $[14,24]$ reported that the prevalence of EsMc were 100\% and $65.1 \%$ in Korean dark sleepers, O. platycephala, from Yugucheon (a branch of Geum-gang) in Gongju-si, Chungcheongnam-do, and Soyang-cheon (a branch of Mangyeong-gang) in Wanju-gun, Jeollabuk-do. The intensity of infection was about 48 and 12 PFI in Yugu-cheon and Soyang-cheon, respectively. On the other hand, the infection status of $M$. orientalis metacercariae was very low in fishes from the irrigation canal of Togyo-jeosuji in this study. They were detected in 43 (29.3\%) out of 147 fish of 6 positive species, and their mean intensity of infection was 4 PFI.

Although more than 5 species of ZTM, i.e., C. sinensis, Metagonimus spp., C. armatus, Echinostoma spp., and M. orientalis, were detected in this study, their individual endemicity was relatively not so high. However, the endemicity of CsMc in 3 fish species, i.e., P. parva, P. herzi and A. gracilis, was relatively high (SI: 72.2, 90.8, and 124.6, respectively). The endemicity of MsMc was high in the pale chub, Z. platypus, (SI: 141.9), and that of CaMc was relatively high in 2 species of chubs, $Z$. platypus and Z. koreanus (SI: 2,115 and 1,118) from the irrigation canal of Togyo-jeosuji, in Cheorwon-gun, Gangwon-do, Korea.

\section{ACKNOWLEDGMENTS}

This study was supported by an Anti-Communicable Diseases Control Program, 2018-2020 (Investigation and analysis on the infections of zoonotic trematode metacercariae in fish intermediate hosts in the Republic of Korea) of National Research Institute of Health (NRIH), Korea Centers for Disease Control and Prevention (KCDCP). We thank Jung-A Kim,
Hee-Ju Kim, and Yeo-Jin Ryu, Department of Parasitology and Tropical Medicine, Gyeongsang National University College of Medicine, Jinju, Korea, for their help in fish examinations.

\section{CONFLICT OF INTEREST}

The authors have no conflicts of interest concerning the work reported in this paper.

\section{REFERENCES}

1. Korea Centers for Disease Control and Prevention, Korea National Institute of Health. National survey of the prevalence of intestinal parasitic infections in Korea, 2012. The 8th Report. Osong, Korea. Korea Centers for Disease Control and Prevention. 2013.

2. Cho SH, Lee KY, Lee BC, Cho PY, Cheun HI, Hong ST, Sohn WM, Kim TS. Prevalence of clonorchiasis in southern endemic areas of Korea in 2006. Korean J Parasitol 2008; 46: 133-137. https://doi.org/10.3347/kjp.2008.46.3.133

3. Kim HK, Cheun HI, Chung BS, Lee KY, Kim TS, Lee SE, Lee WJ, Cho SH. Prevalence of Clonorchis sinensis infections along the five major rivers in Republic of Korea, 2007. Osong Public Health Res Perspect 2010; 1: 43-49. https://doi.org/10.1016/j.phrp.2010. 12.010

4. June KJ, Cho SH, Lee WJ, Kim C, Park KS. Prevalence and risk factors of clonorchiasis among the populations served by primary healthcare posts along five major rivers in South Korea. Osong Public Health Res Perspect 2013; 4: 21-26. https://doi.org/ 10.1016/j.phrp.2012.12.002

5. Jeong YI, Shin HE, Lee SE, Cheun HI, Ju JW, Kim JY, Park MY, Cho SH. Prevalence of Clonorchis sinensis infection among residents along 5 major rivers in the Republic of Korea. Korean J Parasitol 2016; 54: 215-219. https://doi.org/10.3347/kjp.2016.54.2.215

6. Cho SH, Sohn WM, Na BK, Kim TS, Kong Y, Eom K, Seok WS, Lee T. Prevalence of Clonorchis sinensis metacercariae in freshwater fish from three latitudinal regions of the Korean Peninsula. Korean J Parasitol 2011; 49: 385-398. https://doi.org/10.3347/kjp.2011. 49.4.385

7. Cho SH, Lee WJ, Kim TS, Seok WS, Lee TJ, Jeong KJ, Na BK, Sohn WM. Prevalence of zoonotic trematode metacercariae in freshwater fish from Gangwon-do, Korea. Korean J Parasitol 2014; 52: 399-412. https://doi.org/10.3347/kjp.2014.52.4.399

8. Sohn WM, Na BK, Cho SH, Lee SW, Choi SB, Seok WS. Trematode metacercariae in freshwater fish from water systems of Hantangang and Imjingang in Republic of Korea. Korean J Parasitol 2015; 53: 289-298. https://doi.org/10.3347/kjp.2015.53.3.289

9. Sohn WM, Na BK, Cho SH, Park MY, Kim CH, Hwang MA, No KW, Yoon KB, Lim HC. Prevalence of Clonorchis sinensis metacercariae in fish from water systems of Seomjin-gang (River). Korean J Parasitol 2017; 55: 305-312. https://doi.org/10.3347/kjp. 2017.55.3.305 
10. Yoon KB, Lim HC, Jeon DY, Park S, Cho SH, Ju JW, Shin SS, Na $\mathrm{BK}$, Sohn WM. Infection status with Clonorchis sinensis metacercariae in fish from Tamjin-gang (River) in Jeollanam-do, Republic of Korea. Korean J Parasitol 2018; 56: 183-188. https://doi. org/10.3347/kjp.2018.56.2.183

11. Sohn WM, Na BK, Cho SH, Ju JW, Son DC. Prevalence and intensity of Clonorchis sinensis metacercariae in freshwater fish from Wi-cheon stream in Gunwi-gun, Gyeongsangbuk-do, Korea. Korean J Parasitol 2018; 56: 41-48. https://doi.org/10.3347/kjp. 2018.56.1.41

12. Sohn WM, Na BK, Cho SH, Ju JW. Infection status with Clonorchis sinensis metacercariae in fish from Yang-cheon (Stream) in Sancheong-gun, Gyeongsangnam-do, Korea. Korean J Parasitol 2019; 57: 145-152. https://doi.org/10.3347/kjp.2019.57.2.145

13. Sohn WM, Na BK, Cho SH, Lee HI, Lee MR, Ju JW. Kim GO. High endemicity with Clonorchis sinensis metacercariae in fish from Yongjeon-cheon (Stream) in Cheongsong-gun, Gyeongsangbuk-do, Korea. Korean J Parasitol 2021; 59: 97-101. https:// doi.org/10.3347/kjp.2021.59.1.97

14. Sohn WM, Na BK, Cho SH, Kim CH, Hwang MA, No KW, Kim JD. Survey of zoonotic trematode metacercariae in fish from water systems of Geum-gang (River) in Republic of Korea. Korean J Parasitol 2021; 59: 23-33. https://doi.org/10.3347/kjp.2021.59.1.23

15. Sohn WM, Na BK, Cho SH, Lee SW. Infection status with digenetic trematode metacercariae in fishes from coastal lakes in Gangwon-do, Republic of Korea. Korean J Parasitol 2019; 57: 681-690. https://doi.org/10.3347/kjp.2019.57.6.681

16. Sohn WM, Na BK. Infections with digenetic trematode metacercariae in freshwater fishes from two visiting sites of migratory birds in Gyeongsangnam-do, Republic of Korea. Korean J Parasi- tol 2019; 57: 273-281. https://doi.org/10.3347/kjp.2019.57.3.273

17. Togyo-jeosuji in the list of lakes of Korea in Wikipedia - The free encyclopedia: http://en.wikipedia.org

18. Park MS, Kim SW, Yang YS, Park CH, Lee WT, Kim CU, Lee EM, Lee SU, Huh S. Intestinal parasite infections in the inhabitants along the Hantan River, Chorwon-gun. Korean J Parasitol 1993; 31: 375-378. https://doi.org/10.3347/kjp.1993.31.4.375.

19. Kim IS, Kang EJ. Coloured Fishes of Korea. Seoul, Korea. Academy Publishing Company. 1993, pp 1-477, (in Korean).

20. Sohn WM. Fish-borne zoonotic trematode metacercariae in the Republic of Korea. Korean J Parasitol 2009; 47 (suppl): 103-113. https://doi.org/10.3347/kjp.2009.47.S.S103

21. Sohn WM, Na BK, Cho SH, Ju JW, Kim CH, Yoon KB. Infection status with Metagonimus spp. metacercariae in fishes from Seomjin-gang and Tamjin-gang in Republic of Korea. Korean J Parasitol 2018; 56: 351-358. https://doi.org/10.3347/kjp.2018.56.4.351

22. Sohn WM, Na BK, Cho SH, Ju JW, Kim CH, Yoon KB, Kim JD, Son DC, Lee SW. Infections with Centrocestus armatus metacercariae in fishes from water systems of major rivers in Republic of Korea. Korean J Parasitol 2018; 56: 341-349. https://doi.org/10.3347/ kjp.2018.56.4.341

23. Sohn WM, Na BK, Cho SH, Ju JW. Infections status of Isthmiophora hortensis metacercariae in dark sleepers, Odontobutis species, from some water systems of the Republic of Korea. Korean J Parasitol 2018; 56: 633-637. https://doi.org/10.3347/kjp.2018.56.6.633.

24. Sohn WM, Na BK, Cho SH, Ju JW, Kim CH, Hwang MA, No KW, Park JH. Prevalence and infection intensity of zoonotic trematode metacercariae in fish from Soyang-cheon (Stream) in Wanju-gun, Jeollabuk-do, Korea. Korean J Parasitol 2021; 59: 265-271. https://doi.org/10.3347/kjp.2021.59.3.265 